\title{
Combustion of Biogas Released from Palm Oil Mill Effluent and the Effects of Hydrogen Enrichment on the Characteristics of the Biogas Flame
}

\author{
Seyed Ehsan Hosseini, Ghobad Bagheri, Mostafa Khaleghi, and Mazlan Abdul Wahid \\ High Speed Reacting Flow Laboratory, Faculty of Mechanical Engineering, Universiti Teknologi Malaysia, 81310 Skudai, Johor, Malaysia \\ Correspondence should be addressed to Seyed Ehsan Hosseini; seyed.ehsan.hosseini@gmail.com
}

Received 28 September 2014; Revised 31 January 2015; Accepted 27 February 2015

Academic Editor: Kalyan Annamalai

Copyright (C) 2015 Seyed Ehsan Hosseini et al. This is an open access article distributed under the Creative Commons Attribution License, which permits unrestricted use, distribution, and reproduction in any medium, provided the original work is properly cited.

\begin{abstract}
Biogas released from palm oil mill effluent (POME) could be a source of air pollution, which has illustrated negative effects on the global warming. To protect the environment from toxic emissions and use the energy of POME biogas, POME is conducted to the closed digestion systems and released biogas is captured. Since POME biogas upgrading is a complicated process, it is not economical and thus new combustion techniques should be examined. In this paper, POME biogas $\left(40 \% \mathrm{CO}_{2}\right.$ and $\left.60 \% \mathrm{CH}_{4}\right)$ has been utilized as a fuel in a lab-scale furnace. A computational approach by standard $k-\varepsilon$ combustion and turbulence model is applied. Hydrogen is added to the biogas components and the impacts of hydrogen enrichment on the temperature distribution, flame stability, and pollutant formation are studied. The results confirm that adding hydrogen to the POME biogas content could improve low calorific value (LCV) of biogas and increases the stability of the POME biogas flame. Indeed, the biogas flame length rises and distribution of the temperature within the chamber is uniform when hydrogen is added to the POME biogas composition. Compared to the pure biogas combustion, thermal $\mathrm{NO}_{x}$ formation increases in hydrogen-enriched POME biogas combustion due to the enhancement of the furnace temperature.
\end{abstract}

\section{Introduction}

The increasingly strict regulations on pollution formation are pushing the energy and environmental research communities to find cleaner fuel and more efficient combustion technologies. Fossil fuel production is slow and taking many years therefore, the natural reserves of fossil fuels are rapidly exhausting. Many investigations have been carried out to find renewable fuels to replace these transient fossil fuels. Hence, biomass was found to have great potential to be applied in current combustion systems and biofuel could be one of the most important alternative fuels in the future energy mix of the world [1]. Meanwhile, biogas released from anaerobic digestion of biomass and organic wastes could be a source of energy for heat and power generation purposes. By capturing biogas from waste materials, not only an acceptable source of energy is provided but also the environment is protected from greenhouse gas emissions [2]. Unlike other alternative fuels, biogas is not limited geographically and biogas simple production process is one of the most important power points of this fuel [3]. Palm oil as one of the most famous biofuel resources has been developed widely in South East Asian countries like Indonesia, Malaysia, and Thailand and tropical countries in Africa and South America. Palm oil, with approximately $28 \%$ total annual production, is known as the biggest vegetable oil in the world $[4,5]$. However, sustainability of palm oil-based biodiesel production is under question due to POME generation. Huge amount of biogas generated from POME is released to the environment per annum which leads the world to global warming. The low calorific value (LCV) of biogas is the main barrier of biogas utilization development $[6,7]$. Therefore, biogas should be upgraded to remove impurities such as $\mathrm{CO}_{2}$ and $\mathrm{H}_{2} \mathrm{~S}$ [8]. Since biogas upgrading is not economical, pure biogas was applied in flameless combustion technology successfully [9]. Today, with biogas utilization development in heat and power 
generation, comprehensive knowledge about various biogas combustion techniques is needed to select efficient energy conversion by biogas combustion [10]. On the other hand, hydrogen $\left(\mathrm{H}_{2}\right)$ as a clean fuel with low carbon dioxide $\left(\mathrm{CO}_{2}\right)$, carbon monooxide $(\mathrm{CO})$, sulfur oxide $\left(\mathrm{SO}_{x}\right)$, and unburned hydrocarbon (UHC) emissions has great potential as a major fuel in the future [11]. However, $\mathrm{H}_{2}$ is not freely found in nature and when it is used as a fuel, due to its high flammability and the diffusivity of $\mathrm{H}_{2}$, some concerns about safety exist in storage and transport which leads to high explosion risk [12]. Before the 1990s, since most of the researches about $\mathrm{H}_{2}$ enriched combustion were about liquid fuel enrichment, they were not applicable, because atomization and mixing of the species as the mechanical processes play a crucial role in the combustion of $\mathrm{H}_{2}$ enriched liquid fuels. However, the effects of $\mathrm{H}_{2}$ addition to gaseous fuel combustion are more radical because the combustion characteristics of such flames depend heavily on the properties of the gaseous fuels and conditions of the flame. Therefore, $\mathrm{H}_{2}$ enrichment of different gaseous fuels like methane $\left(\mathrm{CH}_{4}\right)$, propane $\left(\mathrm{C}_{3} \mathrm{H}_{8}\right)$, and natural gas $(\mathrm{NG})$ had been developed during the last decade. Ignition of such fuel mixtures under their lean flammability limits ensures the fuel saving targets under the radical development method [13]. The raised temperature due to $\mathrm{H}_{2}$ combustion as well as quick reaction rate with $\mathrm{O}_{2}$ can justify this physical phenomenon. Although hydrogen-enriched gaseous fuel combustion has been developed experimentally and numerically, the effects of hydrogen enrichment on biogas conventional combustion have not been taken into consideration seriously. Since biogas utilization has become one of the valuable energy sources in the world, the effects of hydrogen enrichment of biogas on the conventional flame stability and pollutant formation are investigated in this paper.

1.1. Biogas Composition. Biogas is a flammable renewable gas formed in the anaerobic digestion (AD) of biomass which needs a relatively short formation time. The process of biogas generation and the type of feedstock play important roles in the biogas ingredients mixture [14]. Biogas consists of noncombustible $\mathrm{CO}_{2}$, combustible $\mathrm{CH}_{4}$ with low amounts of hydrogen sulfide $\left(\mathrm{H}_{2} \mathrm{~S}\right)$, water vapor $\left(\mathrm{H}_{2} \mathrm{O}\right)$, carbon monoxide $(\mathrm{CO})$, ammonia $\left(\mathrm{NH}_{3}\right)$, hydrogen $\left(\mathrm{H}_{2}\right)$, nitrogen $\left(\mathrm{N}_{2}\right)$, oxygen $\left(\mathrm{O}_{2}\right)$, dust, and occasionally siloxanes [3]. The most important biogas resources in the world are municipal solid waste (MSW) [15], domestic garbage landfills and old waste deposits [16], palm oil mill effluent [17], sewage sludge [18], cattle ranching and manure fermentation [19], coal mining [20], and agricultural products, rice paddies [21]. The average calorific value of biogas is $21.5 \mathrm{MJ} / \mathrm{m}^{3}$ which is low in comparison with the calorific value of natural gas at $36 \mathrm{MJ} / \mathrm{m}^{3}$. Based on the feedstock, $\mathrm{CH}_{4}$ forms about $40-80 \%$ of the composition of biogas. Since the lower heating value of $\mathrm{CH}_{4}$ is around $34,300 \mathrm{kj} / \mathrm{m}^{3}$ at the standard temperature and pressure, the lower heating value of biogas is about $13,720-27,440 \mathrm{~kJ} / \mathrm{m}^{3}$. The physical characteristics of biogas are usually modeled by $\mathrm{CO}_{2}$ and $\mathrm{CH}_{4}$ because more than $98 \%$ of biogas is a combination of these two gases.
1.2. Hydrogen-Enriched Gaseous Fuel Combustion Modelling. Arrhenius reaction rate of hydrogen-enriched fuel increases due to the growth of the temperature; consequently, the rate of $\mathrm{O}_{2}$ consumption in the lean mixture increases. In the simulation of hydrogen-enriched gaseous fuel combustion, fast chemistry models are superior due to their low computational cost. Indeed, the conserved scalar model as a subcategory of some other models such as flame sheet, laminar flamelet, and conserved scalar models with equilibrium chemistry is defined based on the relationship of the flame thermochemical characteristics as a function of the mixture fraction [22]. Ilbas et al. [23] applied the conserved scalar model to simulate a nonpremixed turbulent combustion of hydrogen-enriched methane. Similar flame was simulated with the eddy dissipation concept (EDC) by Frassoldati et al. [24] and Mardani and Tabejamaat [25] and an unacceptable accuracy was found for mass fraction of minor species like $\mathrm{O}$ and $\mathrm{OH}$ which conducts to wrong expectation for NO formation behavior. It was found that, for modelling the combustion of hydrogen-enriched methane, the steady laminar flamelet method has better performance in terms of minor species prediction [26]. Probability density function (PDF) was calculated for mass fraction of minor and major species, mixture fraction, and temperature by Suo [27]. It was reported that, compared to the equilibrium model, better results within the reaction zone were gained by flamelet model. The simulation of a nonpremixed hydrogenenriched methane bluff-body flame with respect to laminar flamelet model, equilibrium chemistry, flame sheet model, and constrained equilibrium chemistry which was done by Hossain and Malalasekera [28] proves that just major species could be predictable by flame sheet model. Although acceptable results for $\mathrm{H}_{2} \mathrm{O}$ mass fraction and combustion temperature could be achieved by the flame sheet model, overprediction of $\mathrm{CO}_{2}$ is one of the weak points of this model. On the other hand, the reliable results were recorded for temperature, $\mathrm{CO}_{2}$, and $\mathrm{H}_{2} \mathrm{O}$ mass fraction by using the constrained equilibrium model; however, the predicted levels of $\mathrm{CO}$ and $\mathrm{OH}$ mass fraction were not accurate. Similarly prediction of temperature and species mass fraction were reported poor when the equilibrium model was applied. It was concluded that accurate results for temperature and major and minor species mass fraction could be achieved by laminar flamelet model. Hossain and Malalasekera [29, 30] modeled a similar flame applying flamelet model and pointed out that reasonable results could be achieved at upstream locations when a coupled radiation/flamelet model is utilized [31].

1.3. Chemical Reaction Mechanisms in Hydrogen-Enriched Gaseous Fuel Combustion. Various researchers applied different chemical reaction mechanisms in their simulation and it was found that simulation of chemical reaction mechanism plays an important role in the performance of the laminar flamelet model. For instance in the combustion simulation carried out by Ilbas et al. [23] only seven species were employed and Suo [27] applied GRI mechanism with 18 species. GRI2.11 was used by Ravikanti et al. [26] and it 
was found the simulated results are in good agreement with the results of a reduced DRM-22 mechanism [25]. In the combustion simulation done by Frassoldati et al. [24], 600 reactions were implemented when 48 species were considered.

1.4. Hydrogen-Enriched Gaseous Fuel Turbulence Modelling. A great variety of models are introduced for modeling turbulence, chemical reaction, and interaction of these two; yet there is no universal suitable model for all turbulent combustion applications achieved. Each model shows several advantages and disadvantages and poses better performance only in specific applications. Reynolds averaged NavierStokes modeling (RANS), large eddy simulation (LES), and direct numerical simulation (DNS) are the main methods that could be applied for numerical investigation of nonpremixed combustion. In turbulence modelling, despite the Reynolds Stress Model (RSM) yielding proper results for prediction of high strain rate flows and streamline curvature, its function is under question due to different results issued by various researchers. The inability of RSM to predict flow field in the simulation of swirling flame was reported by Meier et al. [32]. The failure of RSM in swirling flow modelling with a processing vortex core (PVC) in the case of local velocity gradients capturing prediction was reported by Erdal and Shirazi [33]. Moreover, the convergence problems of RSM simulation have been reported by some researchers [34, $35]$. Besides, some reports indicate that $k-\varepsilon$ mode has great capacity to model various combustion systems [36]. Dally et al. [37] modelled a bluff body flame with standard modified $k$ $\varepsilon$ and RSM flame sheet model applied with a beta probability density function and claimed that both standard $k-\varepsilon$ and RSM are not capable of predicting the flow field with acceptable accuracy. To improve projecting the flow field, a fine-tuning $k-\varepsilon$ model constant (Ce1 from 1.44 to 1.6 ) was assumed. Based on this assumption, Kim and Huh [38] simulated a bluff body methane/hydrogen flame using a conditional moment closure combustion model to predict $\mathrm{NO}$ formation in a turbulent condition. It was concluded that, although the local results of velocity fields and the variations of the mixture faction were not reliable, the modified $k-\varepsilon$ model is eligible to predict the overall mixture fraction fields and velocity. Indeed, acceptable accuracy was reported by [23$25]$ when fine-tuning of the standard $k-\varepsilon$ model with EDC combustion was simulated. Also, the reliability of both RSM and fine-tuned $k-\varepsilon$ model is enhanced when they applied with laminal flamelet model [26]. The performance of large eddy simulation (LES) was compared to fine-tuned $k-\varepsilon$ model by

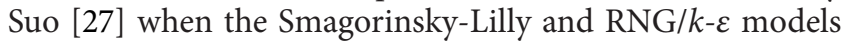
were applied as the subgrid models. It was found that the results of both LES and modified $k-\varepsilon$ model are in good agreement with experimental records.

\section{Methodology}

The objective of this project is mainly to study the impacts of hydrogen addition on the biogas conventional flame stability and pollutant formation. In experimental step, biogas ( $40 \%$
$\mathrm{CO}_{2}$ and $\left.60 \% \mathrm{CH}_{4}\right)$ is injected to the combustor as fuel. In numerical modeling, biogas flow field and related chemical reactions are simulated. After model validation, hydrogen is added to the biogas and the impacts of such change in fuel composition on the temperature distribution in the furnace, flame stability, and pollutant formation are investigated in three cases (Case 1: $0 \% \mathrm{H}_{2}, 40 \% \mathrm{CO}_{2}, 60 \% \mathrm{CH}_{4}$, Case 2: $5 \%$ $\mathrm{H}_{2}, 40 \% \mathrm{CO}_{2}, 55 \% \mathrm{CH}_{4}$, and Case 3: $10 \% \mathrm{H}_{2}, 40 \% \mathrm{CO}_{2}, 50 \%$ $\left.\mathrm{CH}_{4}\right)$.

2.1. Experimental Setup. The diameter and the length of the chamber are $264 \mathrm{~mm}$ and $600 \mathrm{~mm}$, respectively, made of carbon steel. The inside diameter of the furnace is $150 \mathrm{~mm}$ after installation of refractory. Five holes are located at the top of the furnace in a specific distance from burner to record temperature and pollutants by $K$-type thermocouples and gas analyzer, respectively. The diameter of fuel inlet jet is $5 \mathrm{~mm}$ surrounded by holes with $5 \mathrm{~mm}$ diameter for air inlet. A spark ignition system is used to ignite the reactants. Some flow meters are applied to check the flow of air, biogas, hydrogen, and the hydrogen-enriched biogas line. At the first step, the combustion system is run by biogas and for the second and third steps hydrogen is added to th biogas components $5 \%$ and $10 \%$, respectively. Figure 1 displays the experimental setup.

2.2. Numerical Solution. Three-dimensional (3D) simulation is done by ANSYS 14 using ANSYS Modeler to design the chamber and ANSYS Meshing to mesh the combustor [39]. Mesh refinement could be effective to improve the convergence rate and scalar properties; thus grid resolution for smooth flow representation could be ensured. Due to symmetry, only one-eighth of the furnace is simulated. The grid consists of 7769 nodes and 33798 elements.

2.2.1. Boundary Conditions. In each cell, it has been assumed that all the properties have an average value at the center of the cell. The second order upwind scheme is set to calculate the temperature, velocity, and pressure through the governing equations with coupled algorithm. A massweighted averaging method is set to interpolate the velocity values of cell-center to face values. The temperature of fuel and air inlet and pressure outlet is $300 \mathrm{~K}$ and $1.013 \times 10^{5} \mathrm{~Pa}$, respectively, and free stream turbulence is set at $5 \%$. The residual energy equation should drop below $10^{-6}$ and for all other variables it is set at $10^{-3}$ to ensure the convergence of the solution. The swirl velocity of components is neglected in this steady-state CFD simulation and stoichiometric equivalence ratios $(\Phi=1)$ are taken into consideration. The density of biogas includes $40 \% \mathrm{CO}_{2}$ and $60 \% \mathrm{CH}_{4}$ in the standard temperature and pressure is considered $1.2146 \mathrm{~g} / \mathrm{l}$. Table 1 displays various fuel conditions.

2.2.2. Grid Independent Check. The results of numerical solution with 7769 nodes and 33798 elements are in good agreement with the experimental records. The grid independent of the simulation could be tested by changing 
TABLE 1: Fuel data in various cases.

\begin{tabular}{|c|c|c|c|c|c|c|c|c|}
\hline Case & $\mathrm{CO}_{2}$ & $\mathrm{CH}_{4}$ & $\mathrm{H}_{2}$ & Fuel density $\left(\mathrm{kg} / \mathrm{m}^{3}\right)$ & $V_{\text {air }}(\mathrm{m} / \mathrm{s})$ & $V_{\text {fuel }}(\mathrm{m} / \mathrm{s})$ & $\dot{m}_{\text {air }}(\mathrm{kg} / \mathrm{s})$ & $\dot{m}_{\text {fuel }}(\mathrm{kg} / \mathrm{s})$ \\
\hline H0 & 40 & 60 & 0 & 1.2146 & 30 & 22.64 & 0.005544 & 0.00054 \\
\hline H5 & 40 & 55 & 5 & 1.1834 & 30 & 24.78 & 0.005544 & 0.000576 \\
\hline $\mathrm{H} 10$ & 40 & 50 & 10 & 1.1521 & 30 & 27.27 & 0.005544 & 0.000617 \\
\hline
\end{tabular}
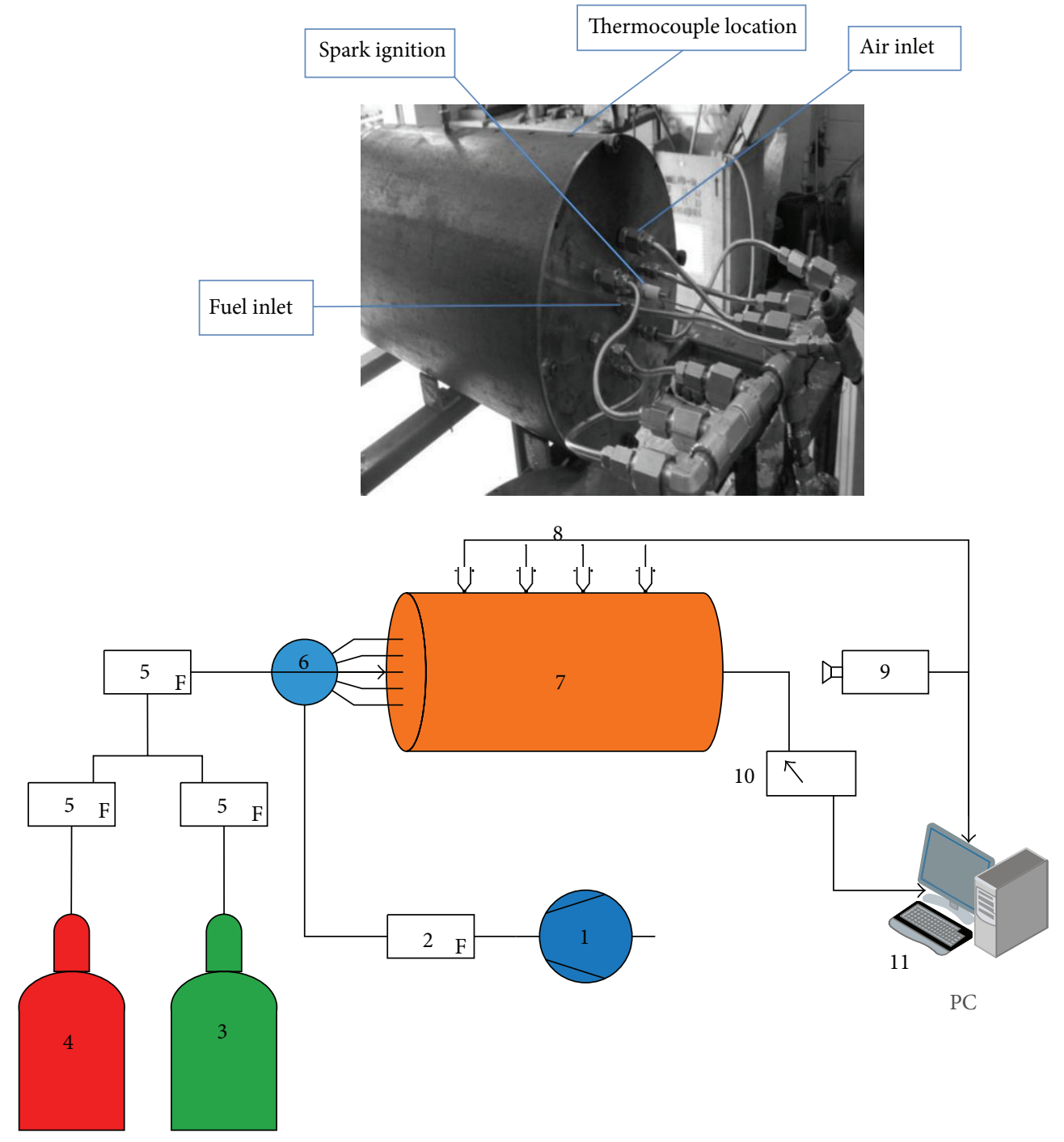
(1) Air compressor
(6) Air distributer
(2) Air flow meter
(7) Furnace
(3) POME biogas
(8) Thermocouples
(4) Hydrogen
(9) Camera
(5) Fuel flow meter
(10) Gas analyzer

FIgURE 1: Experimental setup.

the number of meshes to the finer meshes. In this simulation the number of elements was adopted 33798, 68453, and 100356. These adoptions were motivated by the fact that the most significant conformity to the experimental measurements could be achieved when the mesh is so fine. However, meaningful changes were not observed in the results and the grid independent of solution is confirmed by this test. Figure 2 compares the radial temperature profile of experimental results and simulation data related to biogas conventional combustion. This figure reveals that the captured data from 

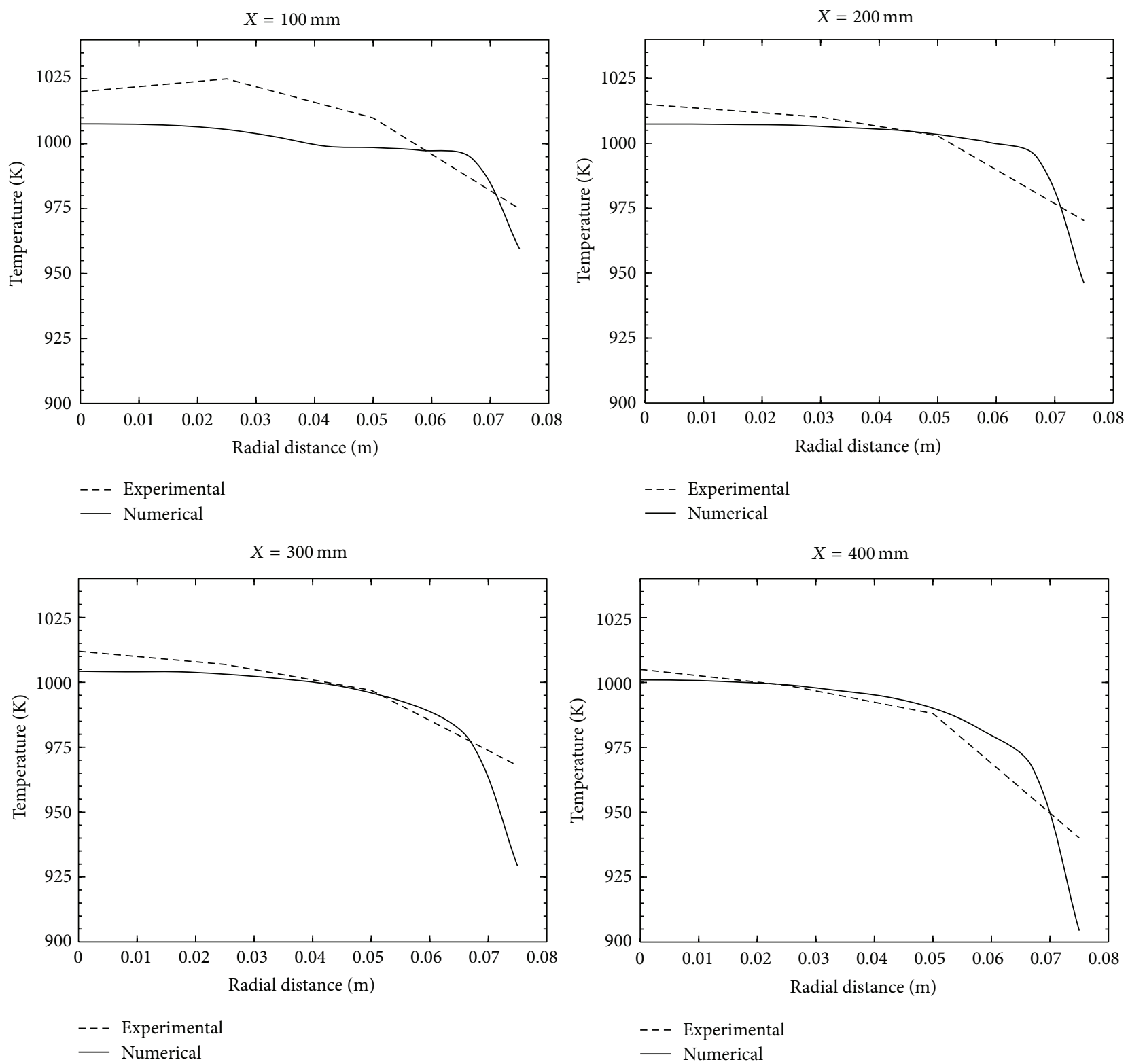

FIGURE 2: The radial temperature profile of experimental results and simulation data.

experimental and simulated study have the same trend in terms of the temperature profile except at $X=100 \mathrm{~mm}$.

2.2.3. Turbulence Modelling. The standard $k-\varepsilon$ model is employed to model conventional flame with the laminar flamelet combustion model. In the standard $k-\varepsilon$ model, $k$ and $\varepsilon$ are modelled with following transport equations:

$$
\begin{aligned}
\frac{\partial}{\partial t}(\rho k)+\frac{\partial}{\partial x_{i}}\left(\rho k u_{i}\right)= & \frac{\partial}{\partial x_{j}}\left[\left(\mu+\frac{\mu_{t}}{\sigma_{k}}\right) \frac{\partial k}{\partial x_{j}}\right] \\
& +P_{k}+P_{b}-\rho \varepsilon-Y_{M}+S_{k},
\end{aligned}
$$

$$
\begin{aligned}
\frac{\partial}{\partial t}(\rho \varepsilon)+\frac{\partial}{\partial x_{i}}\left(\rho \varepsilon u_{i}\right)= & \frac{\partial}{\partial x_{j}}\left[\left(\mu+\frac{\mu_{t}}{\sigma_{\varepsilon}}\right) \frac{\partial k}{\partial x_{j}}\right] \\
& +C_{1 \varepsilon} \frac{\varepsilon}{k}\left(P_{k}+C_{3 \varepsilon} P_{b}\right)-C_{2 \varepsilon \rho} \frac{\varepsilon^{2}}{k}+S_{\varepsilon},
\end{aligned}
$$

where $\mu_{t}, P_{k}$, and $Y_{M}$ represent turbulent viscosity, turbulence kinetic energy production, and the contribution of the fluctuating dilatation in compressible turbulence to the overall dissipation rate, respectively, which are described by

$$
\mu_{t}=\rho C_{\mu} \frac{k^{2}}{\epsilon}
$$




$$
\begin{gathered}
P_{k}=-\rho \overline{u_{i}^{\prime} u_{j}^{\prime}} \frac{\partial u_{j}}{\partial x_{i}}, \\
Y_{M}=2 \rho \varepsilon M_{t}^{2} .
\end{gathered}
$$

2.2.4. Combustion Modelling. The nonpremixed modelling approach is usually applied to the simulation of turbulent diffusion flames with fast chemistry. This model offers many benefits over the eddy dissipation (ED) formulation and allows radical species prediction, dissociation impacts, and precise turbulence-chemistry coupling. The steady laminar flamelet method models a turbulent flame as an ensemble of discrete, steady laminar flames. It is assumed that the individual flamelets have the same structure as laminar flames in simple configurations and are achieved by calculation or experiments. Using detailed chemical mechanisms, FLUENT can calculate laminar opposed-flow diffusion flamelets for nonpremixed combustion. The laminar flamelets are then set in a turbulent flame using statistical PDF methods. The sensible chemical kinetic impacts can be incorporated into turbulent flames by using the laminar flamelet approach. The chemistry can be preprocessed and tabulated, offering enormous computational savings. A set of flamelet profiles in a flamelet library is built in terms of independence scalar dissipation rate and immediate mixture fraction. It means that

$$
P(Z, X)=P(Z) P(X),
$$

where the mean value of the scalar dissipation rate is calculated by

$$
X=C_{x} \frac{\widetilde{\varepsilon}}{\widetilde{k}} Z^{\prime \prime 2} .
$$

$C_{x}$ is equal to 2.5 .

The flamelet library is then integrated with a probability density function (PDF) to compute the average scalar properties:

$$
\widetilde{\emptyset}=\int_{0}^{\infty} \int_{0}^{1} \emptyset(Z, x) P(Z, x) d Z d x .
$$

Mixture fraction could be estimated based on Drake formula [40]. Since GRI3.0 mechanism includes 325 reactions and 53 species, it is superior to GRI 2.11 in terms of up-todate kinetics and accuracy; thus for developing the flamelet library, GRI3.0 mechanism was employed. Indeed, kinetics related to prompt $\mathrm{NO}_{x}$ calculation have been improved in this revision [41].

2.2.5. Radiation Modelling. Prediction of radiative heat transfer is a crucial factor in the simulation of turbulent combustion. Notable discrepancies between numerical predictions and experimental results in terms of pollutant formation and combustion characteristics could emerge if an accurate radiative heat transfer method is not applied. Since $\mathrm{NO}_{x}$ formation is sensitive to the trend of furnace temperature, overprediction of $\mathrm{NO}_{x}$ formation takes place if the radiative heat loss is not considered. For prediction of radiation, discrete ordinates (DO) radiation model is employed in this simulation because of its reasonable computational cost. DO is widely used in such similar computational investigation with no significant error. The related formula and more details of this radiative model can be found in $[42,43]$.

2.2.6. $\mathrm{NO}_{x}$ Formation Modelling. In conventional combustion regime, $\mathrm{NO}_{x}$ formation reduction plays an important role to control acid rain, smog, ozone depletion, and greenhouse effects. $\mathrm{NO}_{x}$ is usually formed in the presence of nitrogen and oxygen within a locally high temperature region. Thermal $\mathrm{NO}_{x}$, prompt $\mathrm{NO}_{x}, \mathrm{~N}_{2} \mathrm{O}$ intermediate mechanism, and fuel-bound nitrogen are mentioned as the main regimes for $\mathrm{NO}_{x}$ formation in the combustion process. At extremely high temperatures within the combustion chamber, $\mathrm{N}_{2}$ and $\mathrm{O}_{2}$ can react through chemical mechanisms that are named Zeldovich formulation. The rate of thermal $\mathrm{NO}_{x}$ formation increases quickly with increasing temperature. Prompt or Fenimore $\mathrm{NO}_{x}$ formation occurs in fuel rich conditions and it was found that the prompt $\mathrm{NO}_{x}$ formation increases near equivalence ratio of 1.4 [44]. $\mathrm{N}_{2} \mathrm{O}$ intermediate mechanism takes place in fuel lean, elevated temperature, and low pressures. $\mathrm{NO}_{x}$ formation by $\mathrm{N}_{2} \mathrm{O}$ mechanism was proposed because of lower flame temperature in the combustion process [45]. Fuel-bound $\mathrm{NO}_{x}$ formation mechanism is related to the presence of nitrogen species in the molecular structure of the fuel. Due to the characteristics of biogas conventional combustion, thermal $\mathrm{NO}_{x}$ and prompt $\mathrm{NO}_{x}$ are considered in the simulation. The transport equation for $\mathrm{NO}$ species formation is

$$
\frac{\partial}{\partial t}\left(\rho Y_{\mathrm{NO}}\right)+\nabla \cdot\left(\rho \vec{v} Y_{\mathrm{NO}}\right)=\nabla \cdot\left(\rho D \nabla Y_{\mathrm{NO}}\right)+S_{\mathrm{NO}} \cdot
$$

$S_{\mathrm{NO}}$ includes thermal $\mathrm{NO}_{x}$ which should be determined by Zeldovich equations and prompt $\mathrm{NO}_{x}$. Zeldovich equations could be written as [46]

$$
\begin{aligned}
& \mathrm{O}+\mathrm{N}_{2} \longleftrightarrow \mathrm{NO}+\mathrm{N} \\
& \mathrm{N}+\mathrm{O}_{2} \longleftrightarrow \mathrm{NO}+\mathrm{O} \\
& \mathrm{N}+\mathrm{OH} \longleftrightarrow \mathrm{NO}+\mathrm{H}
\end{aligned}
$$

The reaction rate constants of reactions are selected from [47] and partial equilibrium approach is considered to estimate the concentration of $\mathrm{OH}$ and $\mathrm{O}$ radicals. The calculation of prompt $\mathrm{NO}_{x}$ formation is done from global model presented in [48]:

$$
\begin{aligned}
\mathrm{CH}+\mathrm{N}_{2} & \longleftrightarrow \mathrm{HCN}+\mathrm{N} \\
\mathrm{N}+\mathrm{O}_{2} & \longleftrightarrow \mathrm{NO}+\mathrm{O} \\
\mathrm{HCN}+\mathrm{OH} & \longleftrightarrow \mathrm{CN}+\mathrm{H}_{2} \mathrm{O} \\
\mathrm{CN}+\mathrm{O}_{2} & \longleftrightarrow \mathrm{NO}+\mathrm{CO}
\end{aligned}
$$



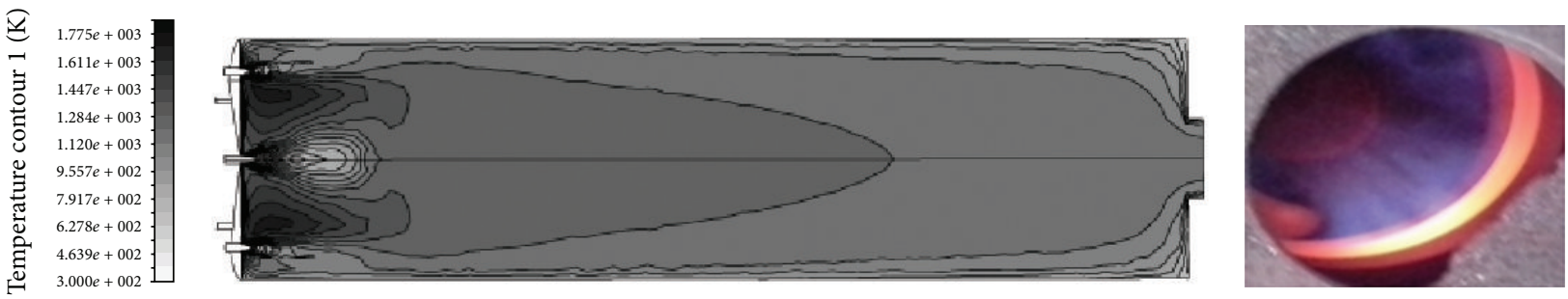

$\mathrm{H} 10$
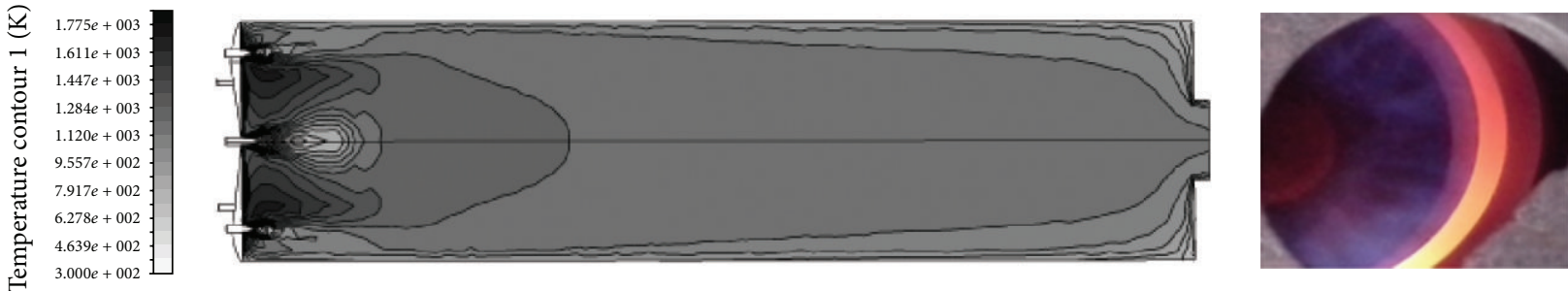

H5
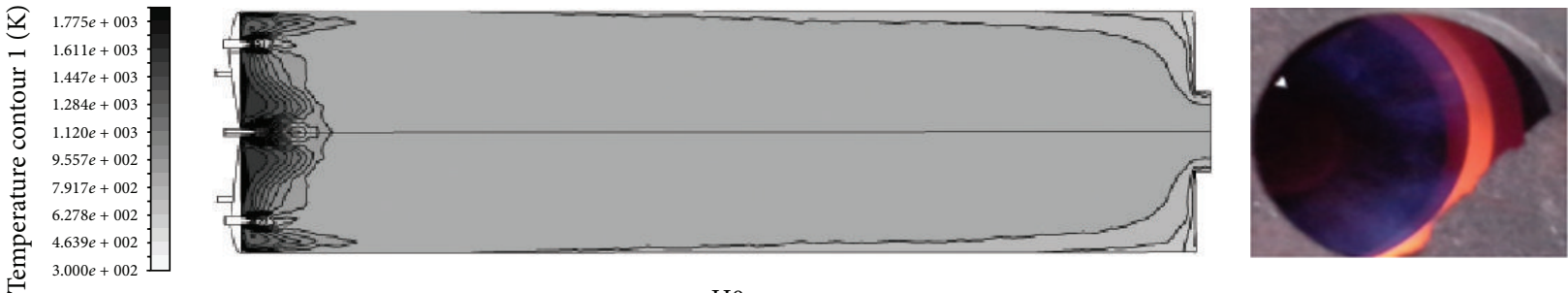

$\mathrm{H} 0$

FIgURE 3: Temperature distribution in the chamber and the pictures of the flames.

To consider the interaction of $\mathrm{NO}_{x}$ formation and turbulence, a PDF of temperature is applied to compute a time average rate of $\mathrm{NO}_{x}$ constitution when generation rate of thermal $\mathrm{NO}_{x}$ and prompt $\mathrm{NO}_{x}$ is calculated. The computed time averaged $\mathrm{NO}_{x}$ results are applied in (6).

\section{Results and Discussion}

The velocity of air jet is kept constant at $30 \mathrm{~m} / \mathrm{s}$ in all cases. When hydrogen is added to the fuel the density of the flow reduces; thus the mass flow rate of the mixture should increase to get stoichiometric conditions. As hydrogen is added to the biogas ingredients by $5 \%$, the structure of biogas flame changes noticeably and the peak of temperature increases. Furthermore, hydrogen addition to the bogus combination causes some changes in the pattern of the flame. The high temperature of the flame shrinks and moves slightly further away from the furnace axis. Indeed, a small hot region is formed at the flame tip and when the concentration of hydrogen raised to $10 \%$, this region becomes bigger. However, the flame temperature is not changed significantly when the percentage of hydrogen intensifies to $10 \%$. Indeed, the length of flame increases when hydrogen is added to the biogas mixture and when further growth in hydrogen percentage is happening, the length of the flame increases. Figure 3 demonstrates the contour of temperature inside the chamber in the three cases.
It can be interpreted that added hydrogen changes the density of biogas mixture and thus the flow rate of mixture increases; thus the flammability of the biogas increases because of hydrogen addition (the flammability limit of $\mathrm{H} 0$, $\mathrm{H} 5$, and $\mathrm{H} 10$ is 9,12 , and 15 (percent by volume), respectively). To further hydrogen content (10\% hydrogen), the flammability of biogas intensifies due to lower density of mixture and higher flow field. Figure 4 displays the numerical results of hydrogen addition effects on the axial temperature and radial temperature profile (at $x=65 \mathrm{~mm}$ ) of the biogas flame. From Figure 4(b), it can be seen that the biogas flame becomes narrow when the percentage of hydrogen content of biogas increases. The flame thickness reduction can be attributed to the enhancement of the mixing. In the simulation of nonpremixed combustion, mixture fraction indicates the mixing rate. While the mixture fraction increases, it can be construed that mixing does not occur properly. Figure 5 displays the mixture fraction in axial and radial directions. When the hydrogen content of biogas increases, the radial spreading rate of mixture fraction decreases which is a sign of mixing growth.

The axial profile of $\mathrm{H}_{2}, \mathrm{CH}_{4}$, and $\mathrm{O}_{2}$ mass fraction in hydrogen-enriched biogas combustion is presented in Figure 6.

The contour of $\mathrm{NO}_{x}$ formation and the effects of hydrogen enrichment on $\mathrm{NO}_{x}$ formation of biogas combustion are presented in Figures 7 and 8, respectively. $\mathrm{NO}_{x}$ formation significantly increases when hydrogen is added to 


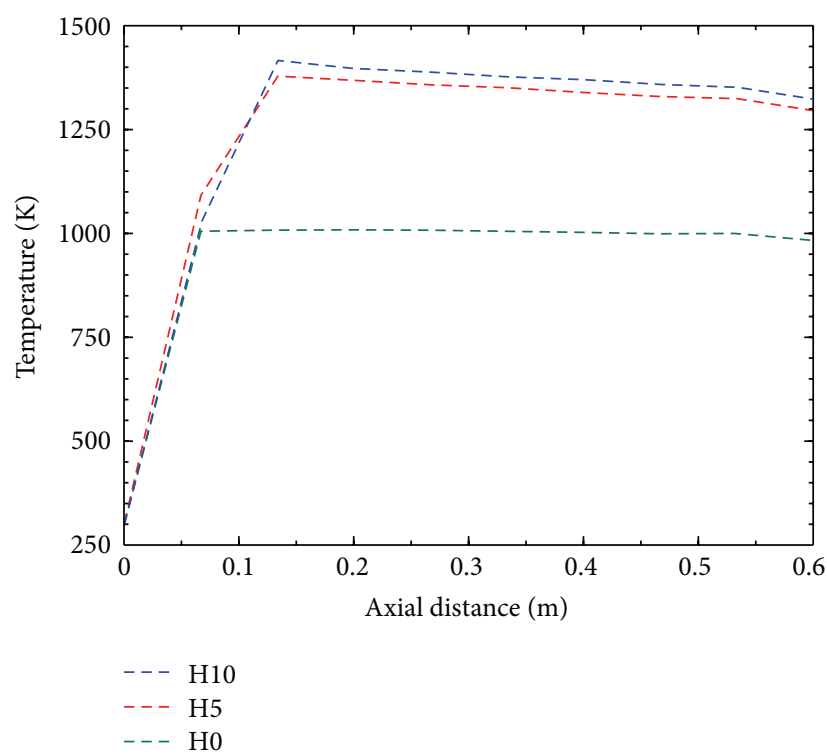

(a) Axial temperature distribution

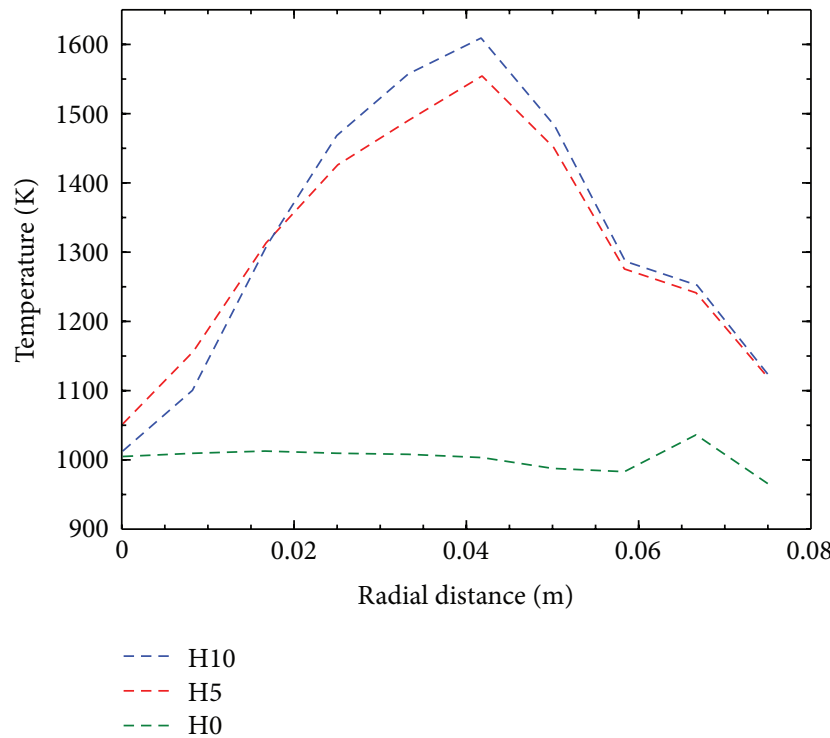

(b) Radial temperature profile at $X=65 \mathrm{~mm}$

FIGURE 4: Effect of biogas hydrogen enrichment on (a) axial temperature distribution and (b) radial temperature profile.

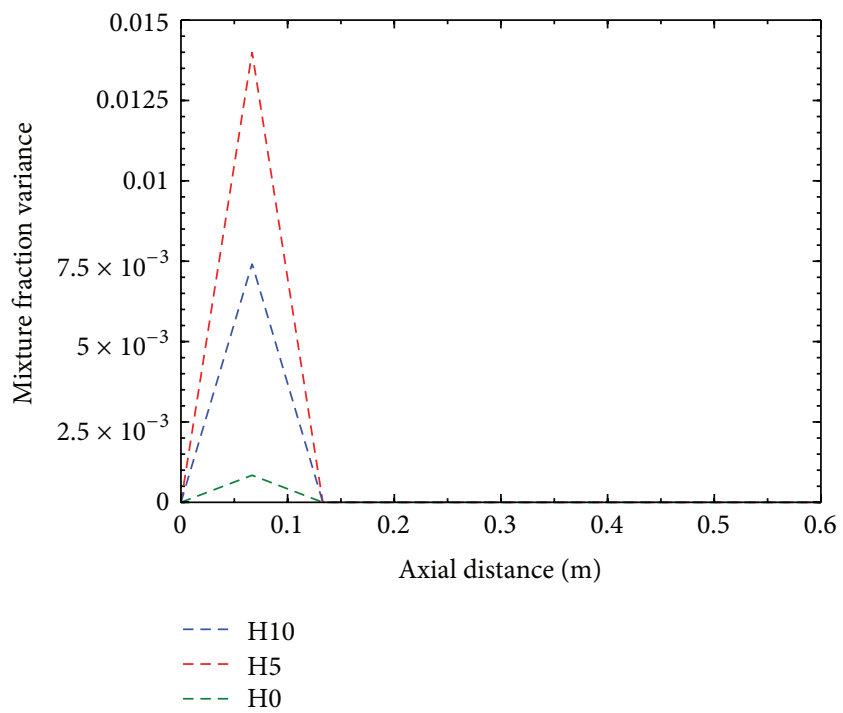

(a)

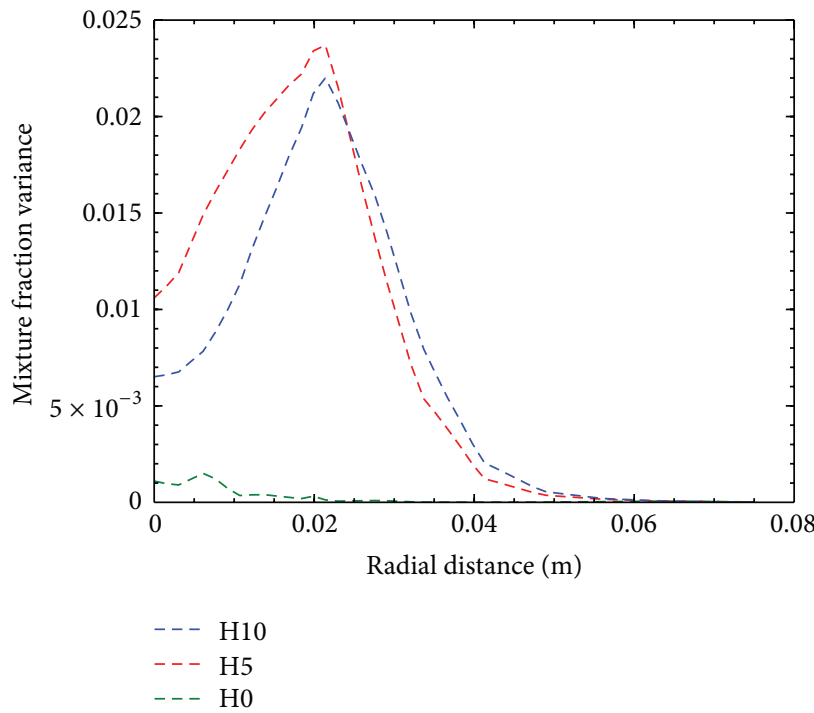

(b)

FiguRE 5: Effect of hydrogen enrichment on the (a) axial profile of mixture fraction and (b) radial profile of mixture fraction in biogas combustion.

the biogas content. Although the contribution of prompt $\mathrm{NO}_{x}$ decreases in the total generated $\mathrm{NO}_{x}$ (because of the carbon content reduction in the fuel mixture), thermal $\mathrm{NO}_{x}$ is increased dramatically due to considerable growth in the flame temperature. It means that hydrogen in the biogas stream contributes to the $\mathrm{NO}_{x}$ formation only through an increase in temperature and consequently via thermal $\mathrm{NO}_{x}$. The maximum temperature in cases $\mathrm{H} 0, \mathrm{H} 5$, and $\mathrm{H} 10$ was recorded $1860 \mathrm{~K}, 1790 \mathrm{~K}$, and $1710 \mathrm{~K}$, respectively. Indeed, from numerical simulation (Figure 3 ) it can be seen that hot spots are developed in case H10. Because of that, $\mathrm{NO}_{x}$ formation region changes with the same pattern that peak temperature distribution region changes.

It was mentioned that Figure 4 indicates that the case H10 has higher temperature from others; however, Figure 7 demonstrates that the $\mathrm{NO}_{x}$ concentration of $\mathrm{H} 10$ is lower than case $\mathrm{H} 5$. The increasing of hydrogen percentage from $5 \%$ to $10 \%$ led the combustion to be more complete. Therefore, 

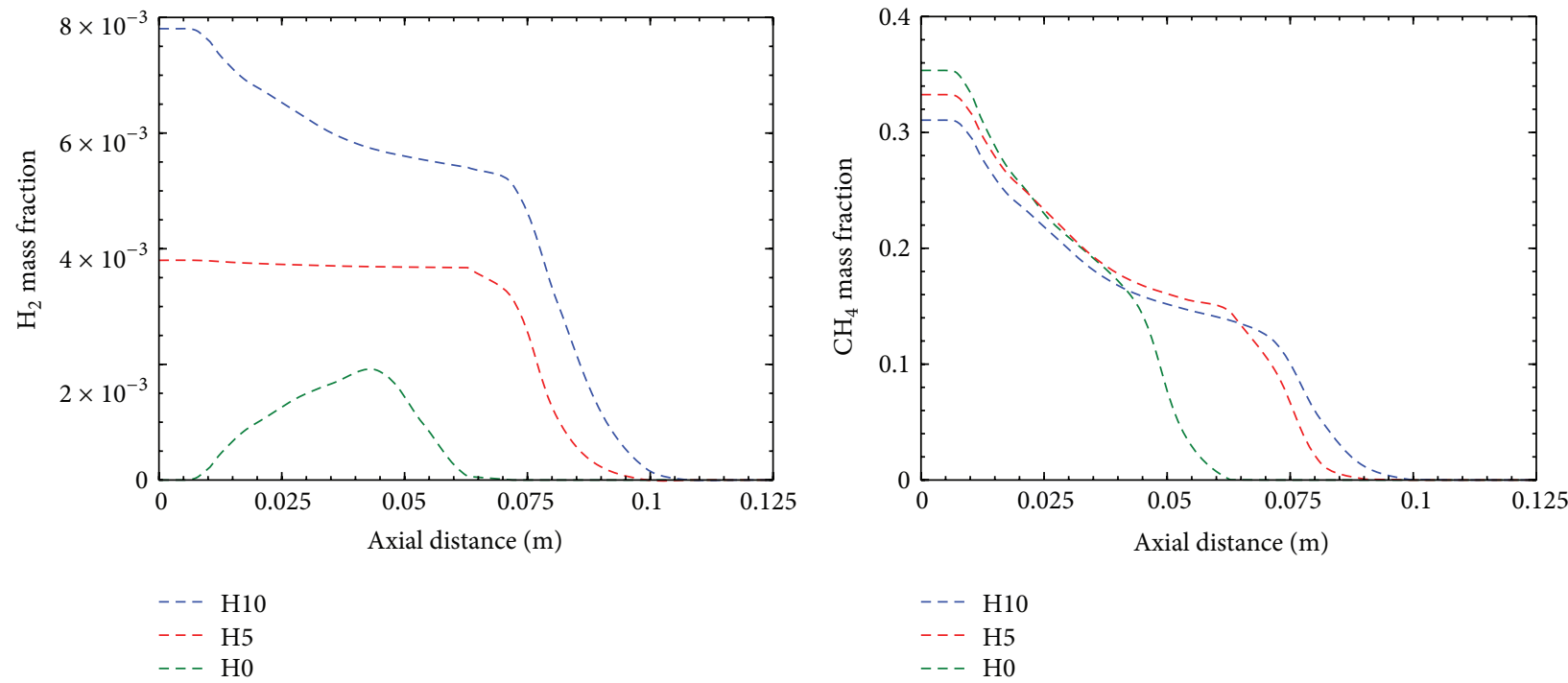

(a)

(b)

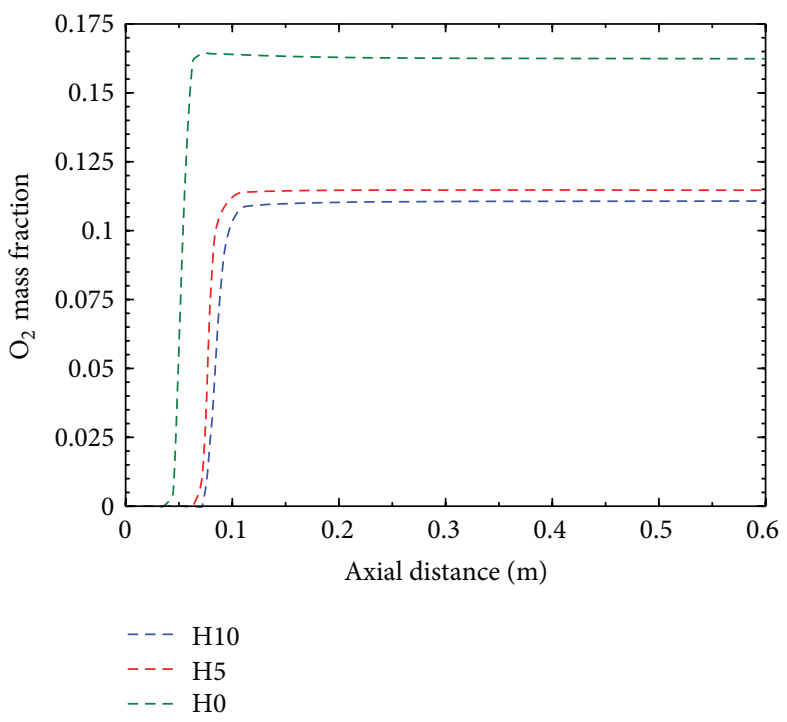

(c)

FIgURE 6: The axial profile of $\mathrm{H}_{2}, \mathrm{CH}_{4}$, and $\mathrm{O}_{2}$ mass fraction in hydrogen-enriched biogas combustion.

according to Figure 6, the concentration of oxygen $\left(\mathrm{O}_{2}\right)$ is less than $\mathrm{H} 5$. It could be argued that lower rate of $\mathrm{NO}_{x}$ production in $\mathrm{H} 10$ is related to oxygen $\left(\mathrm{O}_{2}\right)$ shortage, even though it has higher temperature.

\section{Conclusion}

Although POME biogas could be an acceptable source of energy, LCV of biogas is the most important barrier of this renewable and sustainable fuel development. Since POME biogas upgrading is not economic, new methods should be taken into consideration to improve the combustion of biogas. Since the percentage of hydrogen in the POME biogas components could be controlled by some chemical strategies, the effects of hydrogen enrichment on biogas conventional coflow flame were investigated. Combustion characteristics and flame stability of pure biogas ( $\mathrm{H} 0: 40 \% \mathrm{CO}_{2}$ and $60 \%$ $\mathrm{CH}_{4}$ ) and hydrogen-enriched biogas ( $\mathrm{H} 5: 40 \% \mathrm{CO}_{2}, 55 \%$ $\mathrm{CH}_{4}, 5 \% \mathrm{H}_{2}$ and $\mathrm{H} 10: 40 \% \mathrm{CO}_{2}, 50 \% \mathrm{CH}_{4}, 10 \% \mathrm{H}_{2}$ ) were studied. It was found that adding hydrogen to the biogas content could improve LCV of biogas and consequently the stability of biogas flame increases. Also, the distribution of temperature becomes uniform when hydrogen is added to the biogas. Indeed, the length of the biogas flame is stretched when hydrogen is introduced to the fuel mixture. The simulated results show that the mixing process of fuel and air improves rapidly in the presence of hydrogen. When the concentration of $\mathrm{H}_{2}$ is increased, the density of the inlet fuel 

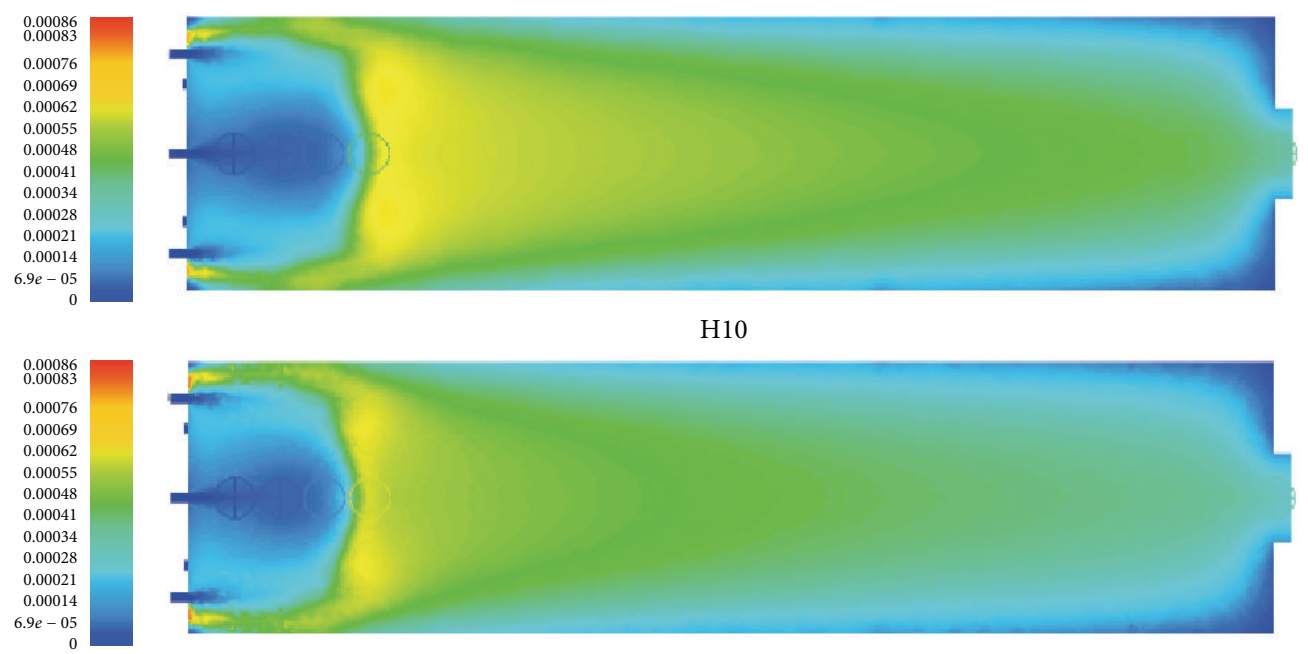

H5

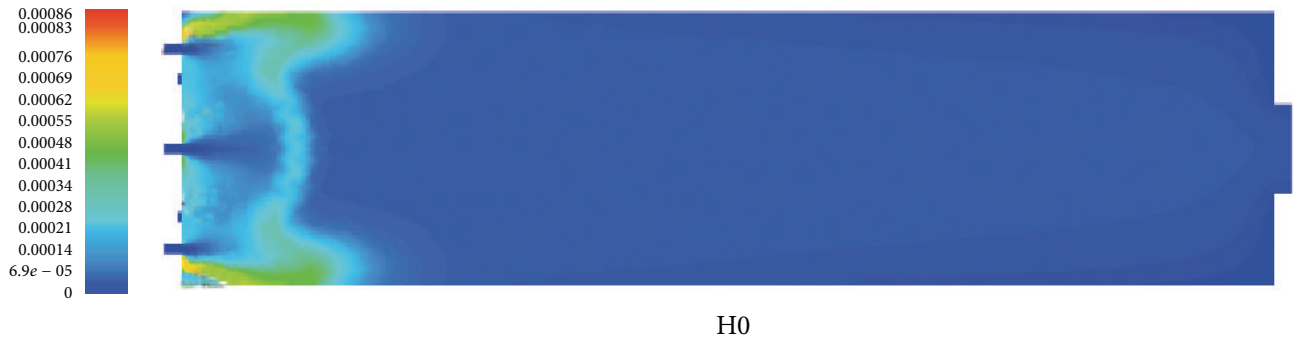

FIGURE 7: $\mathrm{NO}_{x}$ formation contour.

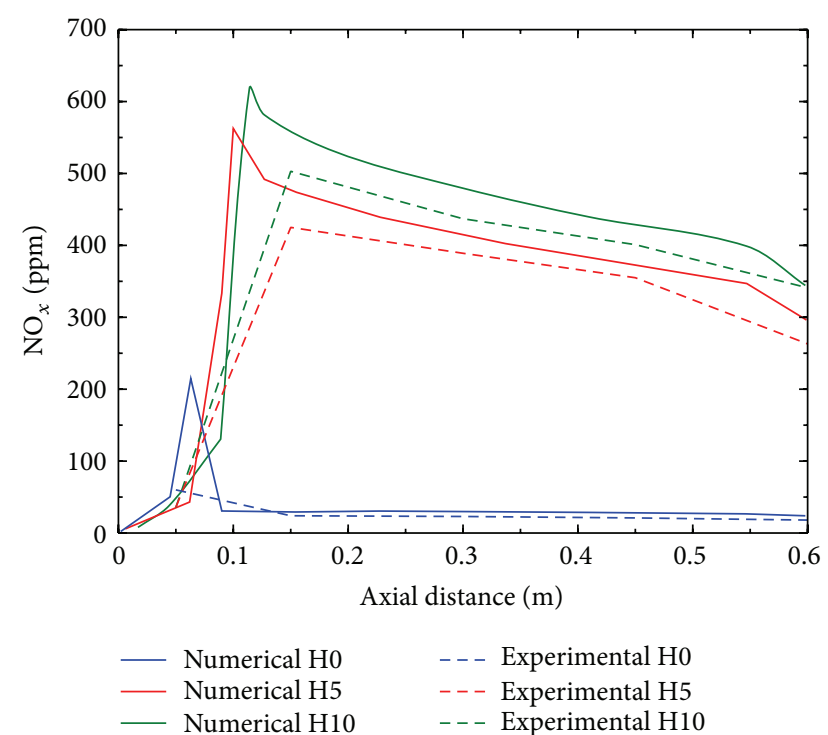

FIgure 8: The axial profile of NO mass fraction in hydrogenenriched biogas combustion.

mixture and thus the flame structure is changed. Compared to the pure biogas combustion, thermal $\mathrm{NO}_{x}$ formation increases in hydrogen-enriched biogas combustion due to temperature enhancement.

\section{Conflict of Interests}

The authors declare that there is no conflict of interests regarding the publication of this paper.

\section{References}

[1] S. E. Hosseini, M. A. Wahid, S. Salehirad, and M. M. Seis, "Evaluation of palm oil combustion characteristics by using the Chemical Equilibrium with Application (CEA) software," Applied Mechanics and Materials, vol. 388, pp. 268-272, 2013.

[2] S. E. Hosseini, M. A. Wahid, and N. Aghili, "The scenario of greenhouse gases reduction in Malaysia," Renewable and Sustainable Energy Reviews, vol. 28, pp. 400-409, 2013.

[3] G. Taleghani and A. S. Kia, "Technical-economical analysis of the Saveh biogas power plant," Renewable Energy, vol. 30, no. 3, pp. 441-446, 2005.

[4] S. B. Hansen, S. I. Olsen, and Z. Ujang, "Greenhouse gas reductions through enhanced use of residues in the life cycle of Malaysian palm oil derived biodiesel," Bioresource Technology, vol. 104, pp. 358-366, 2012.

[5] H. Stichnothe and F. Schuchardt, "Life cycle assessment of two palm oil production systems," Biomass and Bioenergy, vol. 35, no. 9, pp. 3976-3984, 2011.

[6] S. E. Hosseini and M. A. Wahid, "Biogas utilization: experimental investigation on biogas flameless combustion in lab-scale furnace," Energy Conversion and Management, vol. 74, pp. 426432, 2013.

[7] S. Jahangirian and A. Engeda, "Biogas combustion and chemical kinetics for gas turbine applications," in Proceedings of the 
ASME 2008 International Mechanical Engineering Congress and Exposition, Volume 3: Combustion Science and Engineering, pp. 13-22, ASME, Boston, Mass, USA, 2008.

[8] T. Patterson, S. Esteves, R. Dinsdale, and A. Guwy, "An evaluation of the policy and techno-economic factors affecting the potential for biogas upgrading for transport fuel use in the UK," Energy Policy, vol. 39, no. 3, pp. 1806-1816, 2011.

[9] S. E. Hosseini, M. A. Wahid, and A. A. A. Abuelnuor, "Biogas flameless combustion: a review," Applied Mechanics and Materials, vol. 388, pp. 273-279, 2013.

[10] B. Yan, X. Bai, G. Chen, and C. Liu, "Numerical simulation of turbulent biogas combustion," in Proceedings of the Energy Sustainability Conference, pp. 885-896, usa, June 2007.

[11] H. J. Burbano, A. A. Amell, and J. M. García, "Effects of hydrogen addition to methane on the flame structure and CO emissions in atmospheric burners," International Journal of Hydrogen Energy, vol. 33, no. 13, pp. 3410-3415, 2008.

[12] F. Markert, S. K. Nielsen, J. L. Paulsen, and V. Andersen, "Safety aspects of future infrastructure scenarios with hydrogen refuelling stations," International Journal of Hydrogen Energy, vol. 32, no. 13, pp. 2227-2234, 2007.

[13] G. Hu, S. Zhang, Q. F. Li et al., "Experimental investigation on the effects of hydrogen addition on thermal characteristics of methane/air premixed flames," Fuel, vol. 115, pp. 232-240, 2014.

[14] P. Gupta, R. S. Singh, A. Sachan, A. S. Vidyarthi, and A. Gupta, "Study on biogas production by anaerobic digestion of gardenwaste," Fuel, vol. 95, pp. 495-498, 2012.

[15] M. L. de Souza-Santos and K. Ceribeli, "Technical evaluation of a power generation process consuming municipal solid waste," Fuel, vol. 108, pp. 578-585, 2013.

[16] R. M. Barros, G. L. T. Filho, and T. R. da Silva, "The electric energy potential of landfill biogas in Brazil," Energy Policy, vol. 65, pp. 150-164, 2014.

[17] M. J. Chin, P. E. Poh, B. T. Tey, E. S. Chan, and K. L. Chin, "Biogas from palm oil mill effluent (POME): opportunities and challenges from Malaysia's perspective," Renewable and Sustainable Energy Reviews, vol. 26, pp. 717-726, 2013.

[18] W. Yuan and T. J. Bandosz, "Removal of hydrogen sulfide from biogas on sludge-derived adsorbents," Fuel, vol. 86, no. 17-18, pp. 2736-2746, 2007.

[19] D. Raha, P. Mahanta, and M. L. Clarke, “The implementation of decentralised biogas plants in Assam, NE India: the impact and effectiveness of the National Biogas and Manure Management Programme," Energy Policy, vol. 68, pp. 80-91, 2014.

[20] D. Luo and Y. Dai, "Economic evaluation of coalbed methane production in China," Energy Policy, vol. 37, no. 10, pp. 38833889, 2009.

[21] G. K. Kafle and S. H. Kim, "Effects of chemical compositions and ensiling on the biogas productivity and degradation rates of agricultural and food processing by-products," Bioresource Technology, vol. 142, pp. 553-561, 2013.

[22] W. P. Jones and J. H. Whitelaw, "Calculation methods for reacting turbulent flows: a review," Combustion and Flame, vol. 48, pp. 1-26, 1982.

[23] M. Ilbas, I. Yilmaz, and Y. Kaplan, "Investigations of hydrogen and hydrogen-hydrocarbon composite fuel combustion and NOx emission characteristics in a model combustor," International Journal of Hydrogen Energy, vol. 30, no. 10, pp. 1139-1147, 2005.

[24] A. Frassoldati, P. Sharma, A. Cuoci, T. Faravelli, and E. Ranzi, "Kinetic and fluid dynamics modeling of methane/hydrogen jet flames in diluted coflow, Applied Thermal Engineering, vol. 30, no. 4, pp. 376-383, 2010.

[25] A. Mardani and S. Tabejamaat, "Effect of hydrogen on hydrogen-methane turbulent non-premixed flame under MILD condition," International Journal of Hydrogen Energy, vol. 35, no. 20, pp. 11324-11331, 2010.

[26] M. Ravikanti, M. Hossain, and W. Malalasekera, "Laminar flamelet model prediction of $\mathrm{NO}_{x}$ formation in a turbulent bluff-body combustor," Proceedings of the Institution of Mechanical Engineers. Part A: Journal of Power and Energy, vol. 223, no. 1, pp. 41-54, 2009.

[27] D. Y. Suo, "Computational modeling of hydrogen enriched nonpremixed turbulent methane air flames," in Proceedings of the European Combustion Meeting (ECM '05), pp. 1-6, 2005.

[28] M. Hossain and W. Malalasekera, "A combustion model sensitivity study for $\mathrm{CH} 4 / \mathrm{H} 2$ bluff-body stabilized flame," Proceedings of the Institution of Mechanical Engineers, Part C: Journal of Mechanical Engineering Science, vol. 221, no. 11, pp. 1377-1390, 2007.

[29] M. Hossain and W. Malalasekera, "Numerical study of bluffbody non-premixed flame structures using laminar flamelet model," Proceedings of the Institution of Mechanical Engineers Part A: Journal of Power and Energy, vol. 219, no. 5, pp. 361-370, 2005.

[30] M. Hossain and W. Malalasekera, "Modelling of a bluff stabilized $\mathrm{CH} 4 / \mathrm{H} 2$ flame based on a laminar flamelet model with emphasis on NO prediction," Proceedings of the Institution of Mechanical Engineers, Part A: Journal of Power and Energy, vol. 217, no. 2, pp. 201-210, 2003.

[31] M. Hossain, J. C. Jones, and W. Malalasekera, "Modelling of a bluff-body nonpremixed flame using a coupled radiation/flamelet combustion model," Flow, Turbulence and Combustion, vol. 67, no. 3, pp. 217-234, 2002.

[32] W. Meier, O. Keck, B. Noll, O. Kunz, and W. Stricker, "Investigations in the TECFLAM swirling diffusion flame: laser Raman measurements and CFD calculations," Applied Physics B: Lasers and Optics, vol. 71, no. 5, pp. 725-731, 2000.

[33] F. M. Erdal and S. A. Shirazi, "Local velocity measurements and computational fluid dynamics (CFD) simulations of swirling flow in a cylindrical cyclone separator," Journal of Energy Resources Technology, vol. 126, no. 4, pp. 326-333, 2004.

[34] S.-Y. Liu, Y. Zhang, and B.-G. Wang, "Cyclone separator threedimensional turbulent flow-field simulation using the Reynolds stress model," Transaction of Beijing Institute of Technology, vol. 25, no. 5, pp. 377-383, 2005.

[35] A. M. Jawarneh and G. H. Vatistas, "Reynolds stress model in the prediction of confined turbulent swirling flows," Transactions of the ASME, Journal of Fluids Engineering, vol. 128, no. 6, pp. 1377-1382, 2006.

[36] M. R. Halder and S. K. Som, "Numerical and experimental study on cylindrical swirl atomizers," Atomization and Sprays, vol. 16, no. 2, pp. 223-236, 2006.

[37] B. B. Dally, D. F. Fletcher, and A. R. Masri, "Flow and mixing fields of turbulent bluff-body jets and flames," Combustion Theory and Modelling, vol. 2, no. 2, pp. 193-219, 1998.

[38] S. H. Kim and K. Y. Huh, "Use of the conditional moment closure model to predict $\mathrm{NO}$ formation in a turbulent $\mathrm{CH}_{4} / \mathrm{H}_{2}$ flame over a bluff-body," Combustion and Flame, vol. 130, no. 1-2, pp. 94-111, 2002.

[39] Fluent A. 12.0 Theory Guide, Ansys, 2009. 
[40] M. C. Drake and R. J. Blint, "Relative importance of nitric oxide formation mechanisms in laminar opposed-flow diffusion flames," Combustion and Flame, vol. 83, no. 1-2, pp. 185203, 1991.

[41] B. Rohani and K. M. Saqr, "Effects of hydrogen addition on the structure and pollutant emissions of a turbulent unconfined swirling flame," International Communications in Heat and Mass Transfer, vol. 39, no. 5, pp. 681-688, 2012.

[42] G. D. Raithby and E. H. Chui, "Finite-volume method for predicting a radiant heat transfer in enclosures with participating media," Journal of Heat Transfer, vol. 112, no. 2, pp. 415-423, 1990.

[43] J. Y. Murthy and S. R. Mathur, "Finite volume method for radiative heat transfer using unstructured meshes," Journal of Thermophysics and Heat Transfer, vol. 12, no. 3, pp. 313-321, 1998.

[44] L. Pillier, A. El Bakali, X. Mercier et al., "Influence of $\mathrm{C}_{2}$ and $\mathrm{C}_{3}$ compounds of natural gas on $\mathrm{NO}$ formation: an experimental study based on LIF/CRDS coupling," Proceedings of the Combustion Institute, vol. 30, pp. 1183-1191, 2005.

[45] P. C. Malte and D. T. Pratt, "Measurement of atomic oxygen and nitrogen oxides in jet-stirred combustion," Symposium (International) on Combustion, vol. 15, no. 1, pp. 1061-1070, 1975.

[46] C. T. Bowman, "Kinetics of pollutant formation and destruction in combustion," Progress in Energy and Combustion Science, vol. 1, no. 1, pp. 33-45, 1975.

[47] R. K. Hanson and S. Salimian, Survey of Rate Constants in the N/H/O System, Springer, New York, NY, USA, 1984.

[48] G. G. de Soete, "Overall reaction rates of $\mathrm{NO}$ and $\mathrm{N}_{2}$ formation from fuel nitrogen," Symposium (International) on Combustion, vol. 15, no. 1, pp. 1093-1102, 1975. 

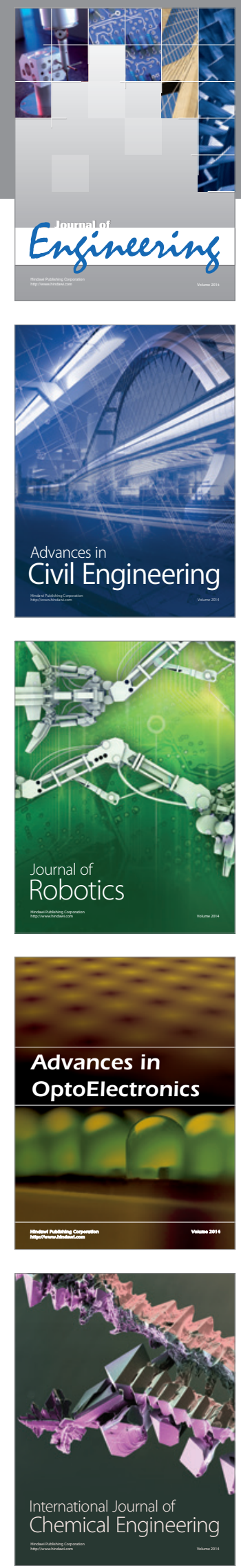

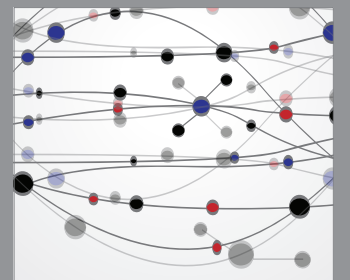

The Scientific World Journal
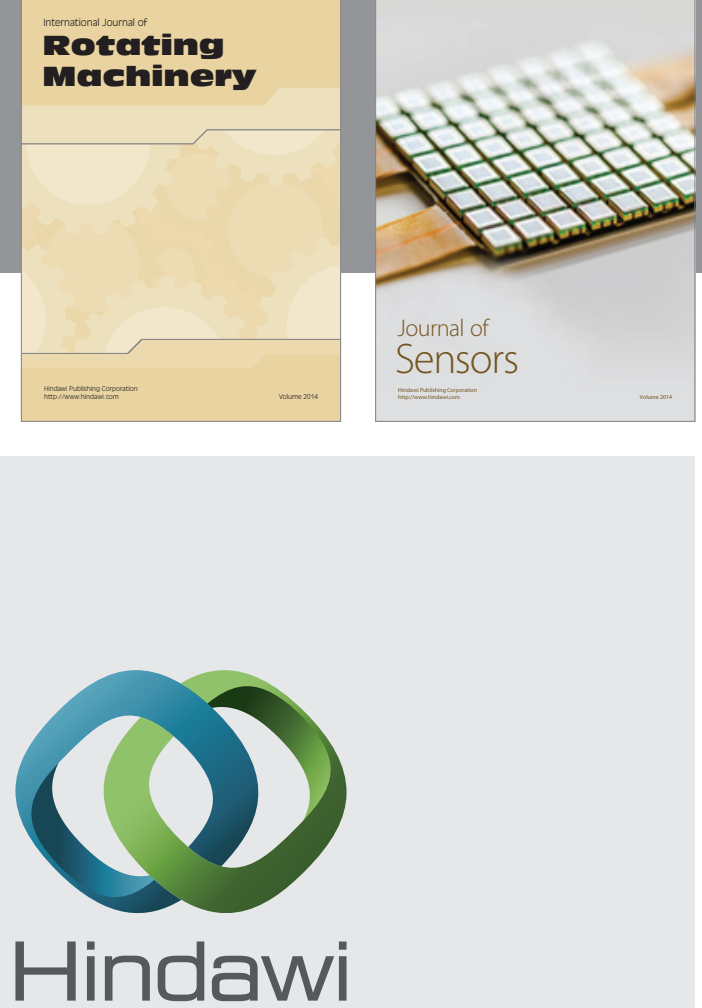

Submit your manuscripts at http://www.hindawi.com
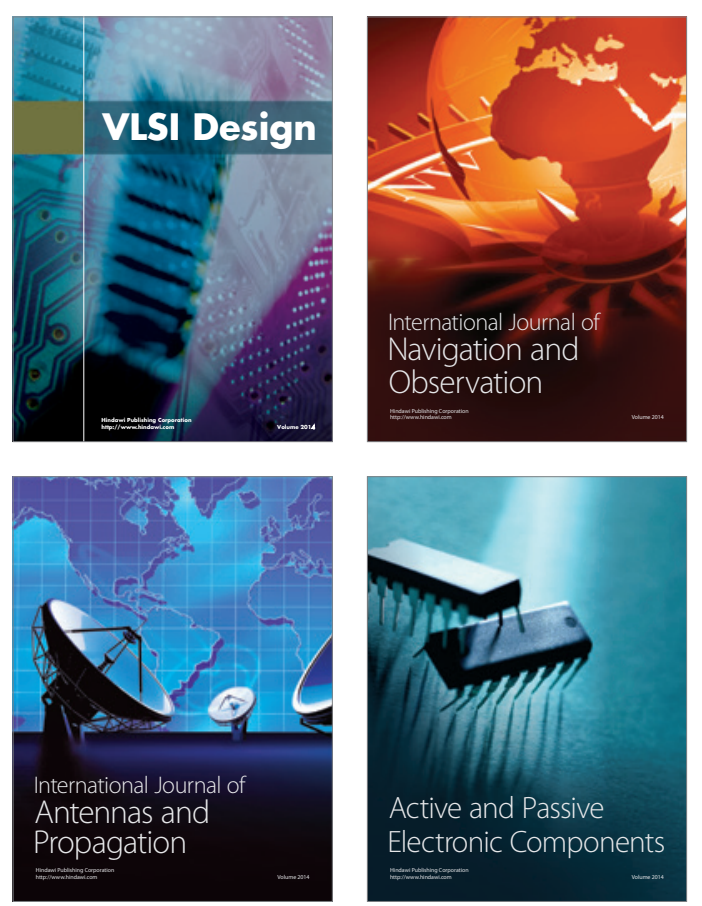
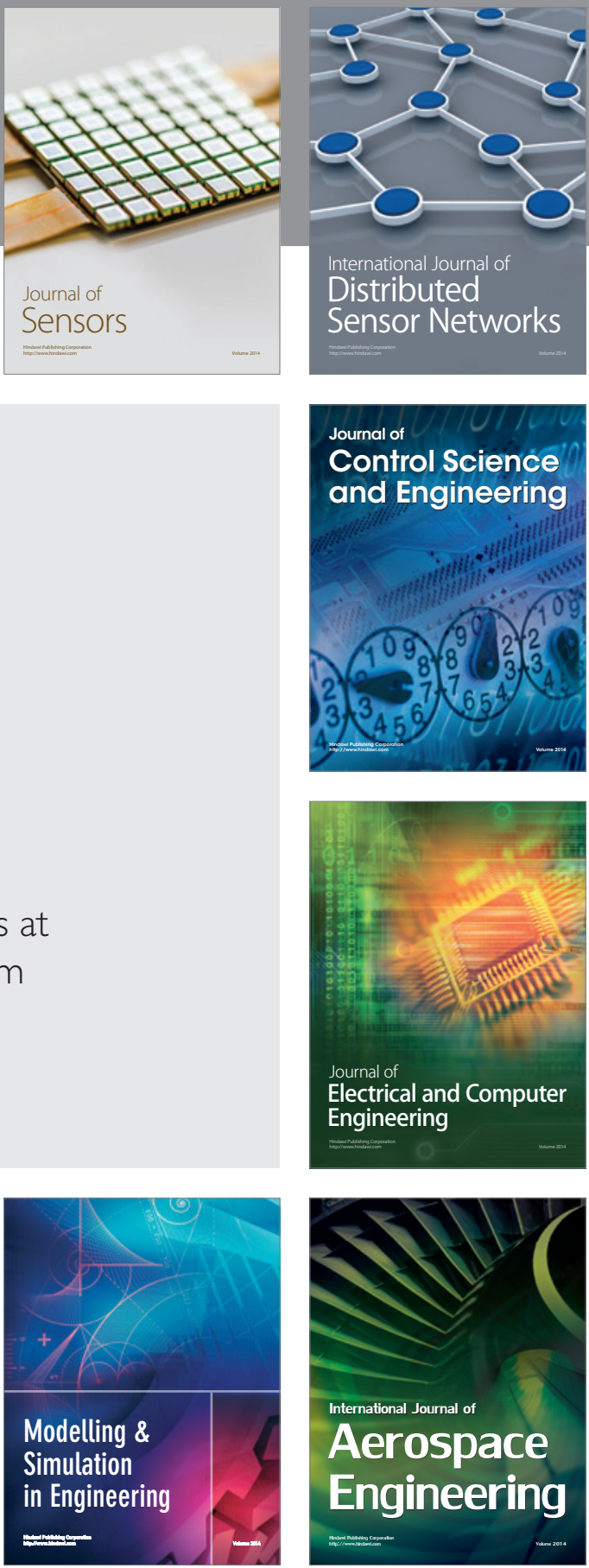

Journal of

Control Science

and Engineering
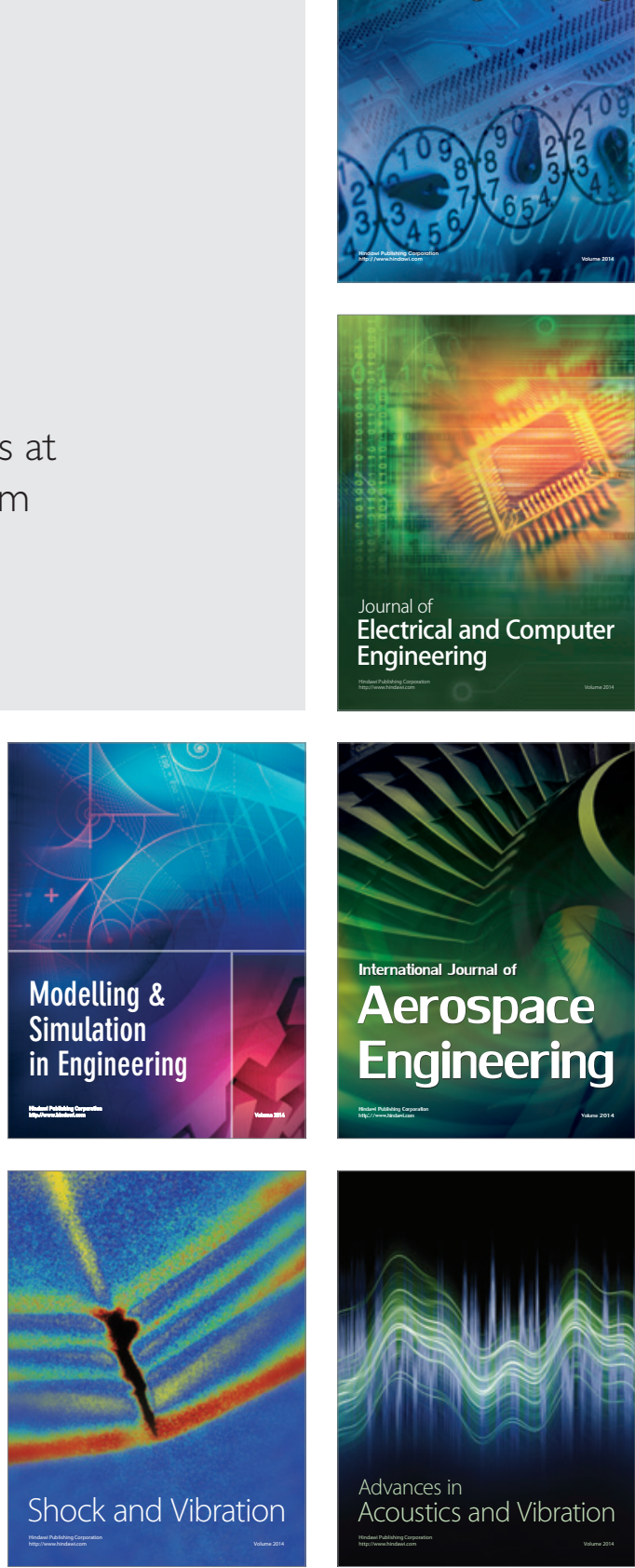